\title{
Electrochemical Reactions to Form Composite Layers Aluminium Oxide-Metal
}

\author{
P. TOMASSI* \\ Institute of Precision Mechanics, Duchnicka 3, 01-796 Warszawa, Poland \\ Processes leading to the formation of the composite layers aluminium \\ oxide-metal have been investigated. Structure, composition, and other prop- \\ erties of this material have been examined. The mechanism of metal elec- \\ trodeposition process is discussed.
}

PACS numbers: 82.45.Jn, 82.45.Qr

\section{Introduction}

In the last period fast development of composite materials is observed and there is a number of new applications in various branches of science and technology. In many cases the use of new composites is the only way to fulfil demands of new materials of special quality.

The topic of this paper is the composite material of oxide matrix composite (OMC)-type with aluminium oxide matrix. The already known process of electrolytic colouring of aluminium [1] is the basis of method of formation of this type of composite material. This method consists of two electrochemical steps:

1. Formation of porous oxide layer by anodic oxidation of aluminium. Uniformly distributed pores are perpendicular to the aluminium substrate surface. The pores diameter depends on oxidation conditions and varies from about 5 to $50 \mathrm{~nm}$. The coating thickness is usually from 1 to $30 \mu \mathrm{m}$ depending on the oxidation time. One should note that the anodic oxide layers $\mathrm{Al}_{2} \mathrm{O}_{3}$ of unique uniform porous structure are now becoming used for formation of new materials by template method [2-10];

2. Electrodeposition of metal inside the pores of oxide matrix. The volume of the pores is progressively filled up beginning from the pore bottom by metal.

*e-mail: tomassi@imp.edu.pl 
The scheme of structure of composite layer is shown in Fig. 1. The metal electrodeposition is usually conducted using alternating polarisation of aluminium electrode with anodic and cathodic cycles. The role of alternating current has not been yet clarified.

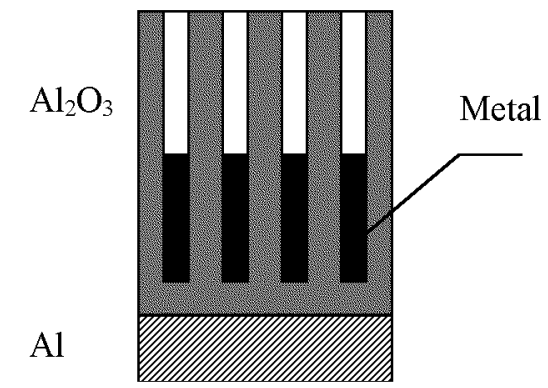

Fig. 1. The structure scheme of composite layers aluminium oxide-metal.

The scope of conducted investigations was to study the reactions of metal electrodeposition inside the $\mathrm{Al}_{2} \mathrm{O}_{3}$ matrix. The results obtained would help to establish the optimum conditions of formation of composite layers of definite properties.

\section{Experimental}

\subsection{Composite coatings formation}

Anodic oxidation of $99.5 \% \mathrm{Al}$ samples was conducted in $1.75 \mathrm{M} \mathrm{H}_{2} \mathrm{SO}_{4}$ solution at temperature $20^{\circ} \mathrm{C}$ with voltage $16 \mathrm{~V}$. The thickness of oxide layer obtained was $15 \mu \mathrm{m}$. The electrodeposition of nickel, copper or tin was performed at temperature $25^{\circ} \mathrm{C}$ in the following solutions:

(a) $\mathrm{NiSO}_{4} 0.1 \mathrm{M}, \mathrm{H}_{3} \mathrm{BO}_{3} 0.5 \mathrm{M}, \mathrm{pH}=5$,

(b) $\mathrm{CuSO}_{4} 0.1 \mathrm{M}, \mathrm{H}_{2} \mathrm{SO}_{4} 0.05 \mathrm{M}, \mathrm{pH}=1$,

(c) $\mathrm{SnSO}_{4} 0.1 \mathrm{M}, \mathrm{H}_{2} \mathrm{SO}_{4} 0.2 \mathrm{M}, \mathrm{pH}=0.5$.

The maximum voltage of alternating current was $16 \mathrm{~V}(\mathrm{Ni})$ or $14 \mathrm{~V}(\mathrm{Cu}, \mathrm{Sn})$. Usually the frequency $50 \mathrm{~Hz}$ was used, but a wide range from 0.1 to $1000 \mathrm{~Hz}$ was checked.

The composite layers were dissolved in acid solutions and the nickel, copper or tin concentrations were measured by the atomic absorption spectrophotometry.

Electrochemical investigations have been performed using transient curve method [11], cathodic polarisation method [12], anodic polarisation method [13], and impedance spectroscopy [14]. 


\section{Results and discussion}

\subsection{Composition and structure examinations}

The uniform composite layers were obtained in the frequency region of 10-100 Hz. With frequencies below $10 \mathrm{~Hz}$ the defects in oxide layer appear. In the light frequency region under $500 \mathrm{~Hz}$ the electrodeposition does not occur and high capacity current is observed.

Chemical analysis of obtained composite layers as well as structure, magnetic properties, gravimetric and electrochemical investigations have been performed.

The concentrations of metals in composite coatings are shown in Fig. 2. In the beginning the deposition rate of tin is the highest; the lowest value has been obtained for nickel. After 10 minutes of electrodeposition the total content of tin and copper was about $1 \mathrm{~g}$ per $\mathrm{m}^{2}$ of aluminium surface and $0.5 \mathrm{~g} / \mathrm{m}^{2}$ in the case of nickel.

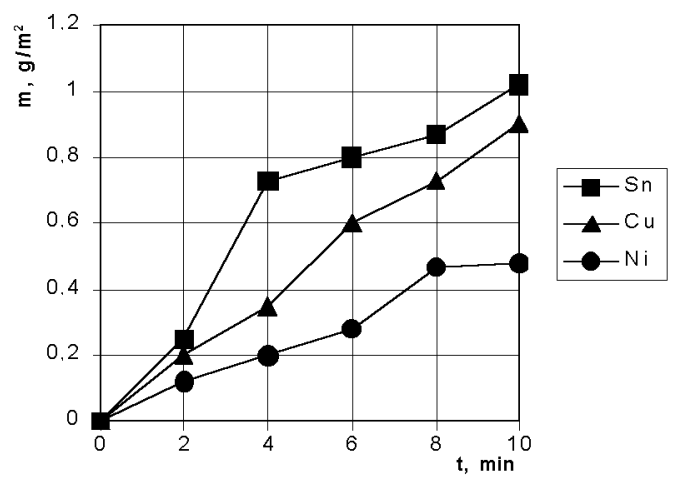

Fig. 2. The metal concentration in composite layers vs. electro-deposition time.

The X-ray analysis has confirmed that the metal deposition starts at the bottom of the pores close to the aluminium surface and the volume occupied by metal increases.

The investigations performed by transmission microscopy have shown that all pores are filled by metal deposit. The diameter of metal particles depends on pore diameter and has been found to be from 5 to $30 \mathrm{~nm}$.

The magnetic properties examinations conducted with Foner magnetometer for $\mathrm{Al}_{2} \mathrm{O}_{3}-\mathrm{Fe}$ system have shown high magnetic anisotropy of the obtained composite layer. The results have confirmed that ferromagnetic Fe particles of a needle shape are located perpendicularly to the surface of aluminium substrate. The similar results were obtained by Hoch and others [15].

By gravimetric measurements the mass of the following coatings was determined:

- without metal deposit, 
TABLE I

Results of gravimetric measurements.

\begin{tabular}{c|c|c|c|c|c}
\hline \hline No. & $\begin{array}{c}\text { Deposited } \\
\text { metal }\end{array}$ & $\begin{array}{c}\text { Time of } \\
\text { deposition }\end{array}$ & $\begin{array}{c}\text { Sealing } \\
+ \text { yes } \\
- \text { no } \\
{[\mathrm{min}]}\end{array}$ & $\begin{array}{c}\text { Mass change in } \\
\text { metal deposition } \\
\text { process } \\
{\left[\mathrm{g} / \mathrm{m}^{2}\right]}\end{array}$ & $\begin{array}{c}\text { Mass change in } \\
\text { sealing process }\end{array}$ \\
\hline 1. & - & - & - & - & - \\
2. & - & - & + & - & +5.97 \\
\hline 3. & $\mathrm{Ni}$ & 5 & - & +1.10 & - \\
4. & $\mathrm{Ni}$ & 10 & - & +1.66 & - \\
5. & $\mathrm{Ni}$ & 5 & + & +1.13 & +6.00 \\
6. & $\mathrm{Ni}$ & 10 & + & +1.91 & +6.22 \\
\hline 7. & $\mathrm{Cu}$ & 5 & - & -4.90 & - \\
8. & $\mathrm{Cu}$ & 10 & - & -5.65 & - \\
9. & $\mathrm{Cu}$ & 5 & + & -6.22 & +4.65 \\
10. & $\mathrm{Cu}$ & 10 & + & -6.22 & +5.40 \\
\hline 11. & $\mathrm{Sn}$ & 5 & - & -6.87 & - \\
12. & $\mathrm{Sn}$ & 10 & - & -7.75 & +6.44 \\
13. & $\mathrm{Sn}$ & 5 & + & -6.40 & +6.60 \\
14. & $\mathrm{Sn}$ & 10 & + & -7.12 &
\end{tabular}

- after metal deposition,

- after additional pores sealing by hydrothermal treatment in boiling water.

The results of gravimetric measurements are shown in Table I. The following conclusions can be formulated:

1. The mass of coating increases during nickel deposition. During deposition of metals from strong acid solutions $(\mathrm{Cu}, \mathrm{Sn})$ the coating mass decreases due to partial dissolution of oxide coating.

2. During sealing operation the coating mass increase is the highest in the case of $\mathrm{Al}_{2} \mathrm{O}_{3}-\mathrm{Sn}$ system.

\subsection{Electrochemical researches}

The examinations performed have shown that electrodeposition process from weak acid solutions $(\mathrm{Ni})$ is inhibited by precipitation of hydroxide deposits as a result of the rise of $\mathrm{pH}$ value inside the pores. During electrodeposition of metals from strong acid solutions $(\mathrm{Cu}, \mathrm{Sn})$ the bigger part of pores can be filled up by metal. As a result of dissolution processes the pore diameter increases and the barrier properties of oxide layer decrease. In anodic cycles the anodic oxidation of aluminium occurs. 


\section{Summary and conclusion}

As a result of investigations presented above the role of alternating polarisation in metal deposition process can be clarified.

In cathodic cycles simultaneously to metal electrodeposition the hydrogen ions reduction occurs. The diffusion of hydrogen ions inside the oxide layer leads to formation of hydrogen bonds and hydrated regions of higher conductivity (active sites). In these regions the probability of electron transport is higher than in other sites, where the current is mainly of ionic character. In the cathodic cycles the new active sites are formed and filled by metal deposit.

In the anodic cycles the repassivation of active sites occurs. That process ensures the barrier layer not to be damaged. The metal electro-deposition can be then effectively conducted with formation of a uniform oxide-metal composite coating.

The optimum current frequencies are in good correlation with times of charge carriers formation determined for aluminium oxide layers by Ebling [16], Hassel and others $[17,18]$.

The author has obtained composite layers consisting the following metals: $\mathrm{Ni}, \mathrm{Cu}, \mathrm{Sn}, \mathrm{Fe}, \mathrm{Co}, \mathrm{Zn}, \mathrm{Cd}, \mathrm{Au}, \mathrm{Pd}, \mathrm{Ag}$. The results of presented investigations will be useful in optimising the process of composite layers formation. The predicted future applications of $\mathrm{Al}_{2} \mathrm{O}_{3}$-metal composites are summarised in Table II.

\section{TABLE II}

Examples of possible applications of $\mathrm{Al}_{2} \mathrm{O}_{3}$-metal composites.

\begin{tabular}{l|l|l}
\hline \hline No. & The useful feature & Examples of application \\
\hline 1. & $\begin{array}{l}\text { Corrosion resistance, decorative } \\
\text { properties }\end{array}$ & $\begin{array}{l}\text { Aluminium elements for building } \\
\text { and architecture }\end{array}$ \\
2. & Radiation absorption & Solar collectors, radiation shields \\
3. & Magnetic properties & Magnetic memories \\
4. & Tribological properties & Sliding parts \\
5. & Catalytic properties & Catalysts
\end{tabular}

In cooperation with Warsaw University of Technology and with University of Warsaw now the new composite material is examined as a catalyst for reduction of nitrogen oxides and as a support for carbon nanotubes [19].

\section{References}

[1] S. Wernick, R. Pinner, P.G. Sheasby, The Surface Treatment and Finishing of Aluminium and its Alloys, Finishing Publications Ltd., Teddington 1987.

[2] N. Baba, H. Masuda, J. Adv. Sci. 5, 61 (1993).

[3] A. Mozelev, A. Surganov, S. Magaino, Electrochim. Acta 44, 3891 (1999). 
[4] G.J. Strijkers, J.H.J. Dalderop, M.A.A. Broeksteeg, H.J.M. Swagten, W.J.M. De Jonge, J. Appl. Phys. 86, 5141 (1999).

[5] B. Lu, S. Bharathulwar, D. Laughlin, D.N. Lambeth, J. Appl. Phys. 87, 4721 (2000).

[6] H. Masuda, K. Fukuda, Science 268, 1466 (1995).

[7] A. Huczko, Appl. Phys. A 70, 365 (2000).

[8] P. Forrer, F. Schlottig, H. Siegenthaler, M. Textor, J. Appl. Electrochem. 30, 533 (2000)

[9] H. Schwanbeck, U. Schmidt, Electrochimica Acta 45, 4389 (2000).

[10] Y. Peng, D.-H. Qin, R.-J. Zhong, H.-L. Li, Mater. Sci. Eng. B 77, 246 (2000).

[11] P. Tomassi, Powtoki Ochronne 15, 2 (1987).

[12] T. Sato, Plat. Sur. Finish. 78, 70 (1991).

[13] I.I. Reklajtis, A.I. Jagminas, Issledovanije v oblasti osazdenija metallov, Institute of Chemistry and Chemical Technology (IChChT AN LSSR), Vilnus 1988, p. 128, (in Russian).

[14] A. Królikowski, P. Tomassi, in: Proc. Polish Chemical Society Congress, September 1994, Warsaw.

[15] L. Hoch, Ch. Raub, G. Rauscher, F. Reesing, H. Liebscher, Galvanotechnik 86, 734 (1995).

[16] D. Ebling, Ph.D. Thesis, Heinrich Heine University, Dusseldorf 1991.

[17] A.W. Hassel, M.M. Lohrengel, Electrochimica Acta 40, 433 (1995).

[18] A.W. Hassel, M.M. Lohrengel, J.W. Schulze, Matalloberflache 50, 19 (1996).

[19] H. Lange, A. Huczko, Y.Q. Zhu, W.K. Hsu, H.W. Kroto, D.R.M. Walton, P. Tomassi, in: Proc. 2nd Intern. Workshop on the Science and Application of Nanotubes "Nanotube 2001", July 2001, Potsdam (Germany). 